\title{
Gritical study of coleoptile elongation controlled by IAA and ABA II. Epidermal surfaces analysed by SEM
}

\author{
Rose-Marie Hofer, Claude Schlienger and Paul-Emile Pilet \\ Institute of Plant Biology and Physiology, University of Lausanne, 1005 Lausanne, Pl. de la Riponne, \\ Switzerland
}

(Received January 31, 1977)

\begin{abstract}
Cell wall surfaces of wheat coleoptiles treated with IAA and ABA were observed using SEM. On in situ and in vitro cultured material, formation of some "cracks" was observed after stimulated elongation. Sizes and distribution of these "cracks" were related to longitudinal stress, which increased with increased cell wall elongation.
\end{abstract}

It is now possible to study the surfaces of plant tissues using Scanning Electron Microscopy (SEM) $(10,11,15)$. Such a technique allows clear discernment of changes in cell wall structure $(3,12,16)$. On the other hand, the growth of a plant organ is usually tested only by measurement of its axial length (13). And it is well established that wheat coleoptile elongation may be controlled by exogenous indolyl3 -acetic acid (IAA) $(8,9,19)$ and by abscisic acid (ABA) $(1,20)$. Consequently, it was of interest to analyse-using SEM-the changes occuring in cell wall surfaces during growth of wheat coleoptiles treated or not with IAA and ABA (17).

\section{Material and methods}

Coleoptiles of Triticum vulgare, cv. Probus, were cultured for $72 \mathrm{hr}$ (dark; 25 $\pm 1^{\circ} \mathrm{C}$ ), and seedlings with $20 \pm 1 \mathrm{~mm}$ coleoptiles were selected. As previously described (17), two series of assays were performed; 1) in situ experiments using coleoptiles of intact seedlings on filter paper with active solutions and 2) in vitro experiments using $5 \mathrm{~mm}$ segments excised at $5 \mathrm{~mm}$ from the tip (subapical segments) and immersed in active solutions (17).

For SEM, two methods of sample preparation were used.

1. After fixation $(6 \mathrm{hr})$ in a $4 \%$ buffered glutaraldehyde solution, dehydration in a graded series of acetone and drying treatments (critical point drying apparatus with liquid $\mathrm{CO}_{2}$ ), the specimens were coated with a metallic gold layer (about $40 \mathrm{~nm}$ thick) and observed at $15 \mathrm{keV}(11,18)$.

2. Fresh material was immediately frozen in liquid nitrogen on the sample holder, and placed in the microscope at $-150^{\circ} \mathrm{C}$ for direct observation at $5 \mathrm{keV}$, without any coating (7).

\section{Results and discussion}

The epidermis of coleoptiles cultured in situ in the presence of several concentrations of IAA showed some "cracks" (Fig. 1A), when no "cracks" could be detected in either the control (Fig. 1B) or in ABA-treated coleoptiles (Fig. 1C). 

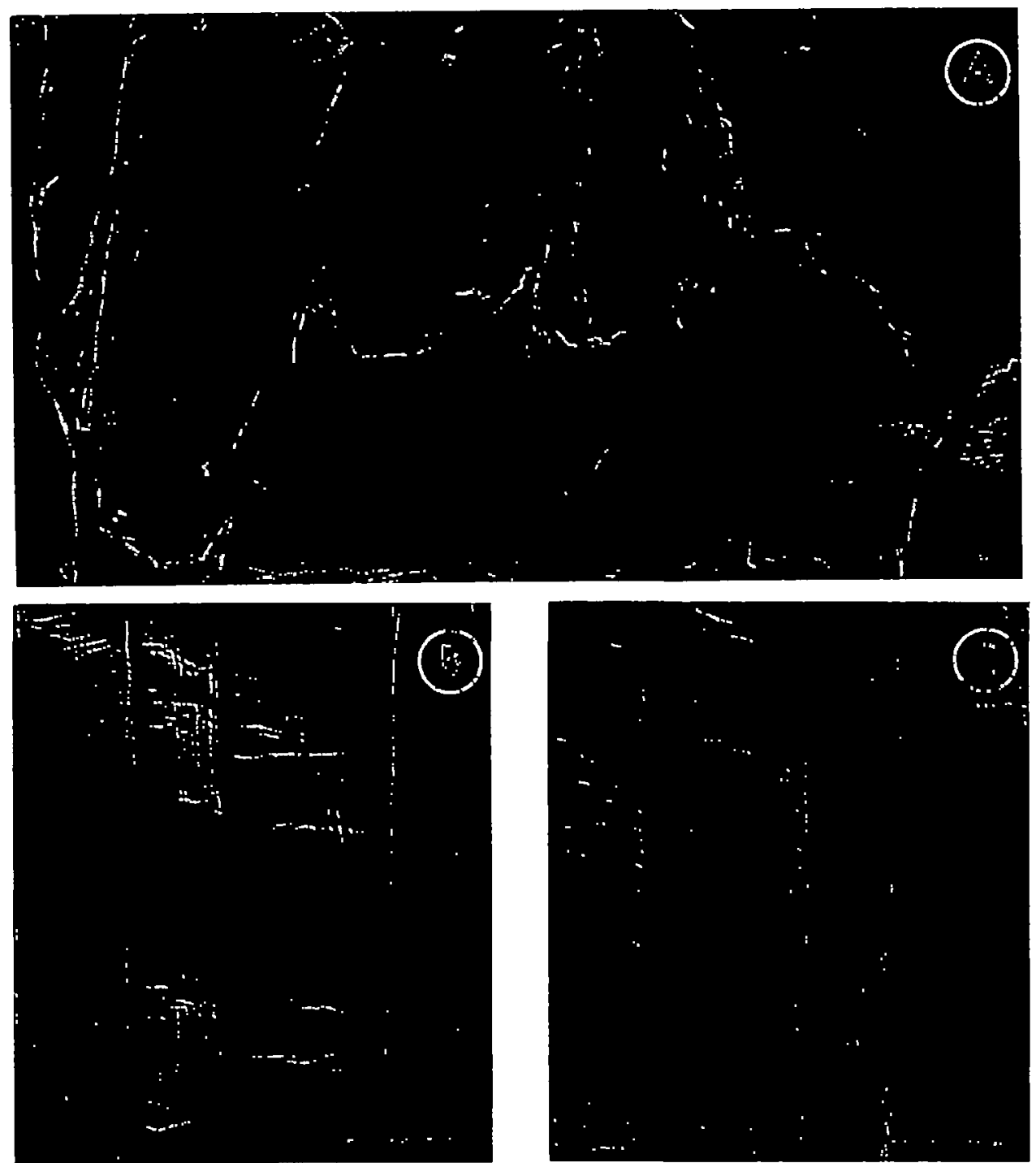

Fig. 1. SEM micrographs of wheat coleoptile surfaces. A: Effect of IAA $\left(10^{-4} \mathrm{M}\right)$ after $24 \mathrm{hr}$ of in situ culture. B: Control after $24 \mathrm{hr}$ of in situ culture. C: Effect of ABA $\left(3.8 \times 10^{-0} \mathrm{M}\right)$ after $24 \mathrm{hr}$ of in situ culture. Scale bars: $10 \mu \mathrm{m}$.

In order to study the formation of these "cracks", $5 \mathrm{~mm}$ segments excised at $5 \mathrm{~mm}$ from the tip, an area especially sensitive to IAA and ABA treatments (17), were cultured in vitro. As can be seen in Fig. 2, the apical end (A) of such a segment, characterized by the greatest growth velocity (17), showed the largest "cracks". Their density was also maximal at this end of the segment (Fig. 3). The length and incidence of "cracks" increased with increasing IAA concentrations, as can be seen in Fig. 2 and 3 on one hand, and in Fig. 4A and 4B on the other. The sizes of the "cracks" (Fig. 5), as well as their density (Fig. 6) were also enhanced when 


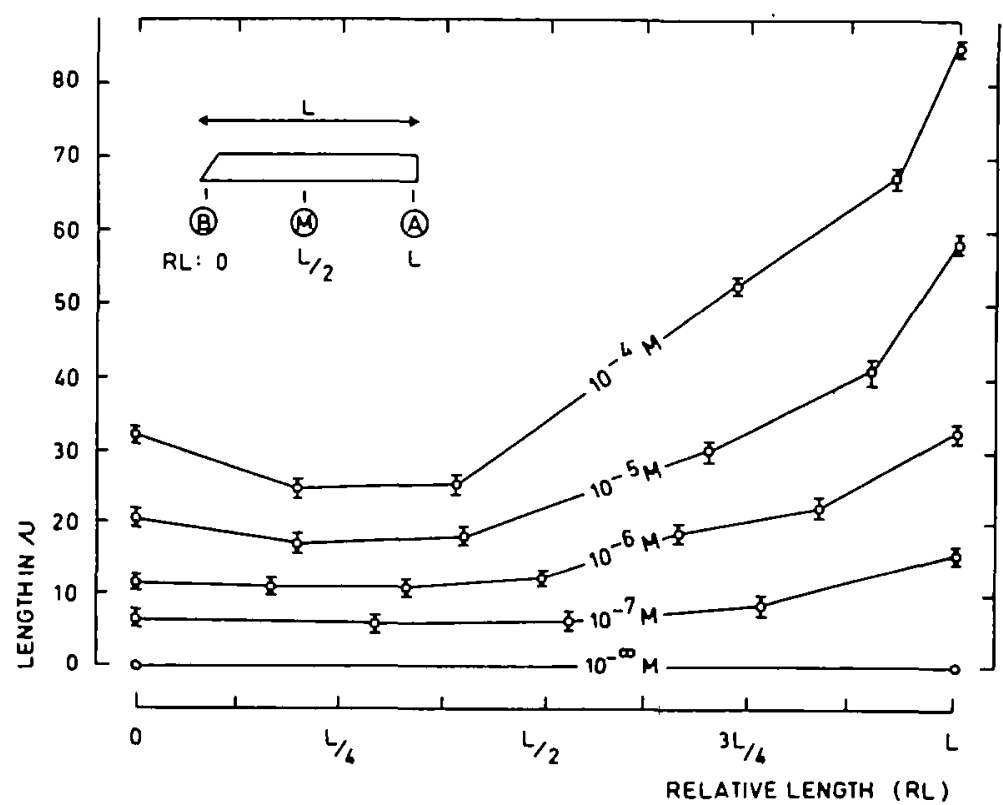

Fig. 2. Variations of the length (in $\mu m \pm$ standard error) of "cracks" along the subapical segments of wheat coleoptiles treated $24 \mathrm{hr}$ with IAA at secoral concentrations $\left(0\right.$ to $\left.10^{-4} \mathrm{x}\right)$.

the incubation was longer. For the control and for ABA treated segments, no "cracks" could be detected after $24 \mathrm{hr}$.

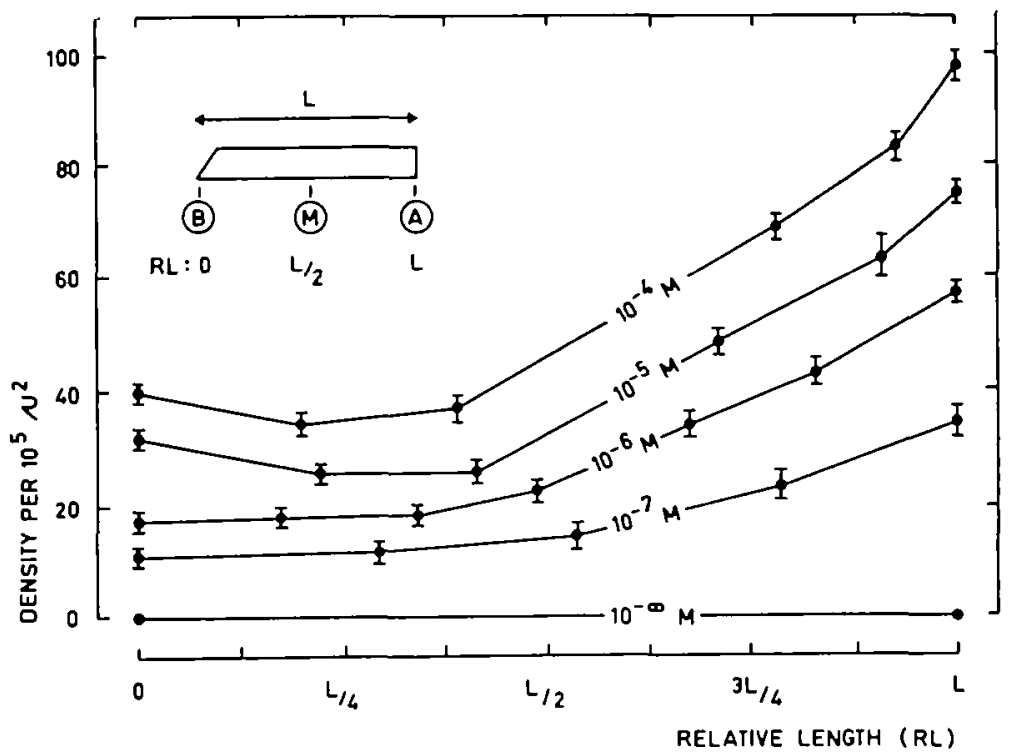

Fig. 3. Changes in the density of the "cracks" (expressed by the number of "cracks" per 105 $\mu m^{8} \pm$ standard error) along the subapical segments of wheat coleoptiles treated $24 \mathrm{hr}$ with $I A A$ at several concentrations $\left(0\right.$ to $\left.10^{-4} \mathrm{M}\right)$. 

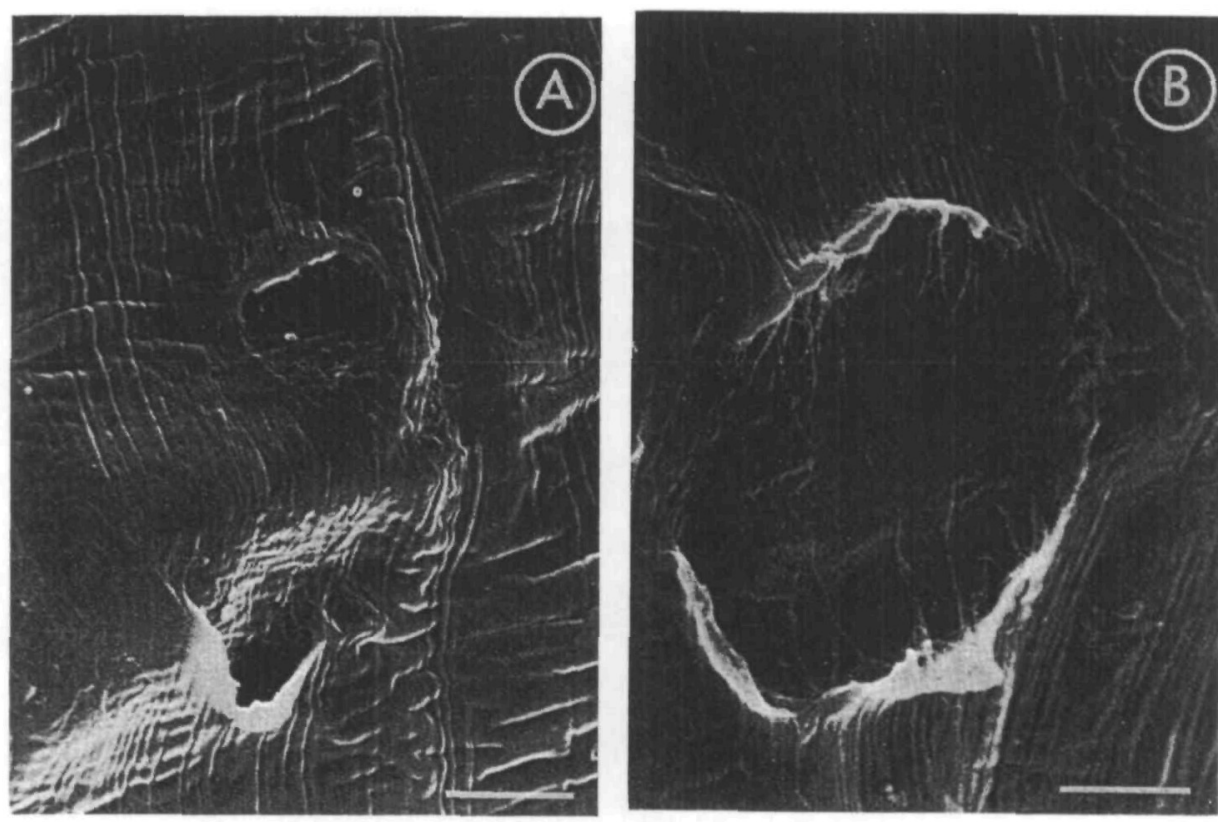

Fig. 4. SEM micrographs of wheat coleoptile surfaces. A: Effect of IAA $\left(10^{-0} M\right)$ after $24 \mathrm{hr}$ of culture. B: Effect of IAA $\left(10^{-5} \mathrm{M}\right)$ after $24 \mathrm{hr}$ of culture. Scale bars: $5 \mu \mathrm{m}$.

It should be noted that all these results were obtained on samples analyzed after fixation, dehydration and drying. But quite similar "cracks" could be also observed

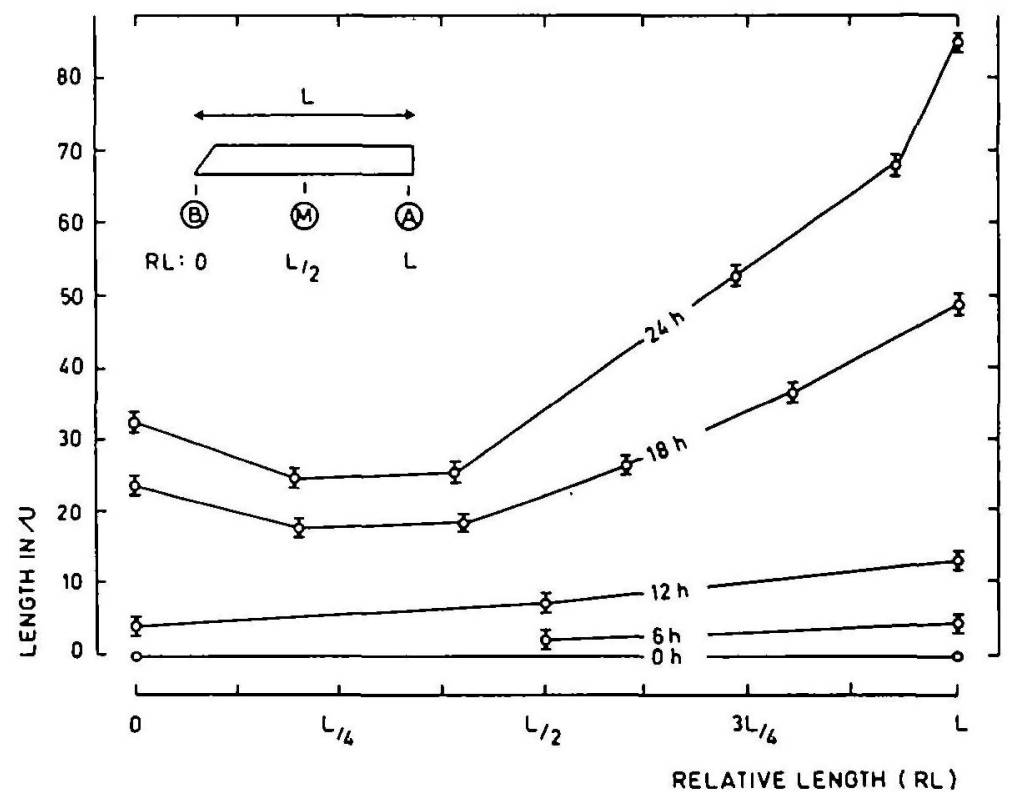

Fig. 5. Variations of the length (in $\mu m \pm$ standard error) of "cracks" along the subapical segments of wheat coleoptiles in relation with tims ( 0 to $24 \mathrm{hr}$ ) of culture in presence of IAA $\left(10^{-4} \mathrm{M}\right)$. 


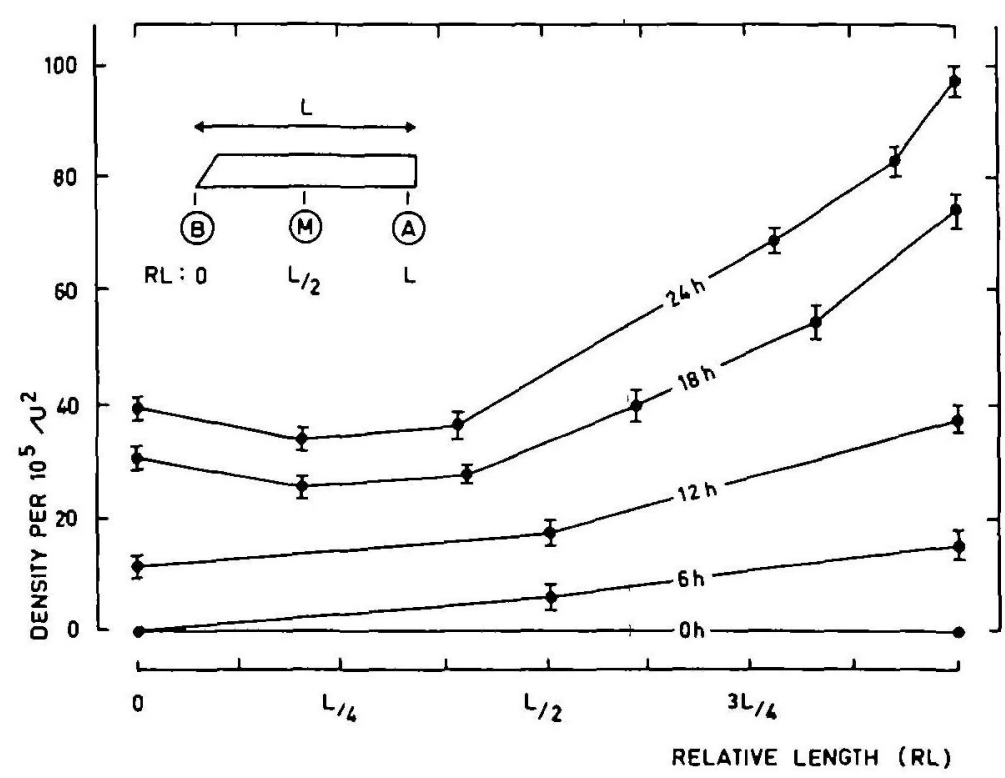

Fig. 6. Changes of the densily of the "cracks" (see Fig. 3) along the subapical segments of wheat colooptiles in relation with time ( $O$ to $24 \mathrm{hr}$ ) of culture in the presence of IAA (10-4 $\mathrm{x}$ ).

when employing frozen material without any coating (Fig. 7A). In contrast, for the control and for the ABA treated segments no "cracks" could be detected (Fig. 7B).
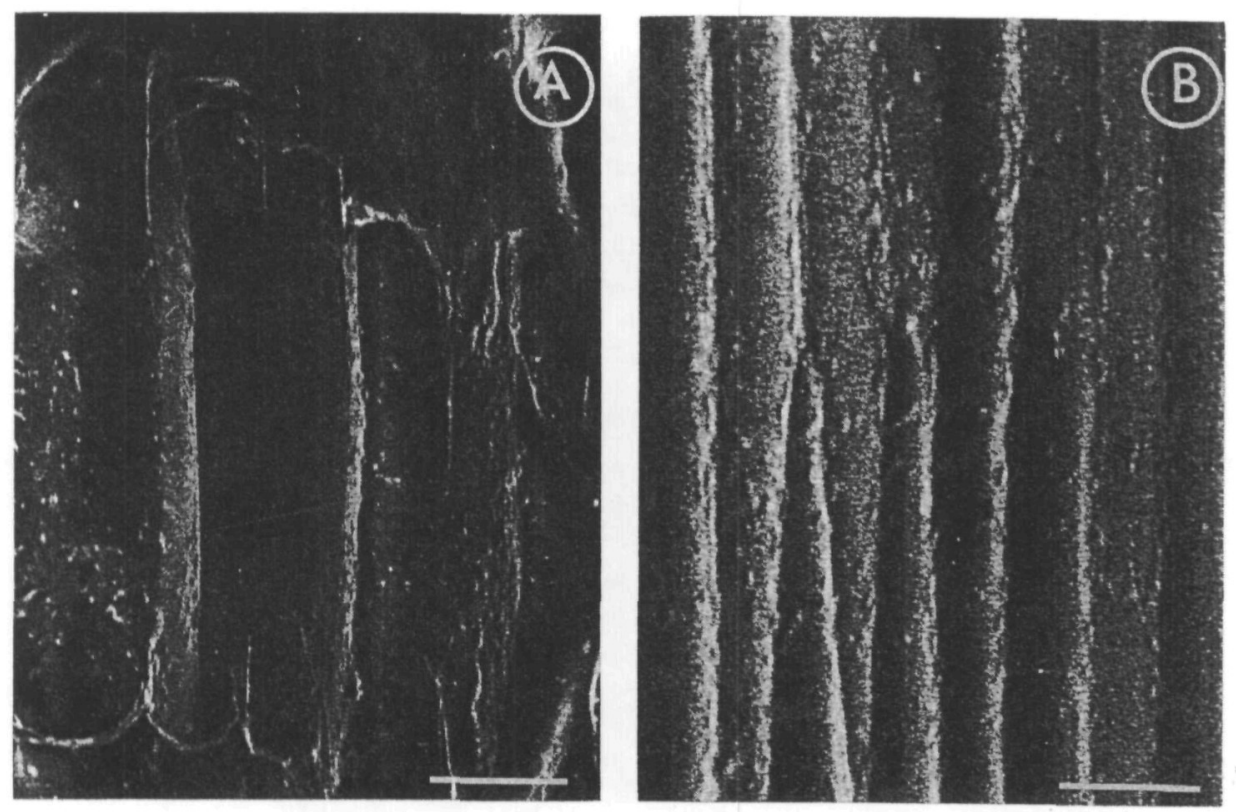

Fig. 7. SEM micrographs of frozen wheat colooptils suffaces. A: Effect of IAA $\left(10^{-4} \mathrm{x}\right)$ after $24 \mathrm{hr}$ of culture. B: Control after $24 \mathrm{hr}$ of culture. Scale bars: $20 \mu \mathrm{m}$. 
Relations between the formation of these "cracks" and the extension of the coleoptile segments seem clearly established in the present material. The number of cells of the outer epidermis of the coleoptile remains constant from the "embryo" phase to maturity (2), but a slight increase in cell number for the other layers takes place before the coleoptile is $18 \mathrm{~mm}$ long. In the tested segments, growth is directly proportional to the elongation of all the cells, while the epidermal cells already present the largest elongation velocity. Exogenous IAA induces a growth stimulation which seems to be correlated to proton excretion, promoting cell wall loosening $(6)$. The longitudinal stress increasing within the walls during cell extension (5) may act on the polylamellate structure of the wall. In such a structure, successive lamellae show a mainly longitudinal orientation of microfibrils alternating with lamellae mainly transversally oriented (4) and promote the formation of "cracks".

It is quite easy to believe that such longitudinal stress, when it is strong enough, could be the source of the "cracks". In fact, these "cracks" were only observed, on the epidermal surface when the longitudinal growth was significantly stimulated. In contrast, they were never found in the control even after $24 \mathrm{hr}$ of incubation or, much less, on the coleoptile segments treated with $\mathrm{ABA}$ at a concentration for which significant inhibition of elongation was obtained $(14,17)$.

The several steps of "crack" induction and the physical changes in the microfibril structure during the "crack" formation are now under study.

\section{References}

( I) Addicott, F. T.: Biochemical aspects of the action of abscisic acid. In Plant Growth Substances. Edited by D. J. Carr. p. 272-280. Springer Verlag, Berlin, 1972.

(2) Avery, G. S., Jr. and P. R. Burkholder: Polarized growth and cell studies on the Avena coleoptile, phytohormone test object. Bull. Torrey Bot. Club 63: 1-15 (1936).

( 3 ) Burgess, J. and P. J. Linstead: Scanning electron microscopy of cell wall formation around isolated plant protoplasts. Planta $131:$ 173-178 (1976).

(4) Chafe, S. C. and A. B. Wardrop: Fine structural observations on the epidermis. I. The epidermal cell wall. ibid. 107: 269-278 (1972).

(5) Cleland, R.: Cell wall extension. Ann. Rev. Plant Physiol. 22: 197-222 (1971).

(6) Cleland, R.: Auxin-induced hydrogen ion excretion: correlation with growth, and control by external $\mathrm{pH}$ and water stress. Planta 127: 233-242 (1975).

(7) Dumas, C.: Le stigmate et la secrétion stigmatique. Thèse Universilé Claude-Bornard-Lyon (1975).

( 8 ) Göring, H., H.-P. Möller und W. Bleiss: Kurzzeitkinetik des Streckungswachstums und des Younschen Moduls von Weizenkoleoptilen nach IES-Applikation und Wasserpotentialänderungen. Biachom. Physiol. Pflanzen 168: 411-420 (1975).

(9) Hertel, R. and R. Flory: Auxin movement in corn coleoptiles. Planta 82: 123-144 (1968).

(10) Heslop-Harrison, Y. and J. Heslop-Harrison: Scanning electron microscopy of leaf surfaces. In Proc. 2nd Annual Scanning Electron Microscopy Symposium p. 119-126, 1969.

(11) Homes, J.: Scanning electron microscopy of carrot cells and embryoids growing in vitro under various culture conditions. In Proc. Workshop on SEM and Plant Sci. Chicago, p. 335-342, 1974.

(12) Jones, M. G. K. and V. H. Dropkin: Scanning electron microscopy of syncytial transfer cells induced in roots by cyst-nematodes. Physiol. Plant Pathol 7: 259-263 (1975).

(13) Pilet, P. E.: L'action des auxines sur la croissance des cellules. In Handbuch der Pflanzenphysiologie Edited by W. Ruhland. Vol. XIV: p. 784-806. Springer Verlag, Berlin, 1961. 
(14) Rehm, M. M. and M. G. Cline: Rapid growth inhibition of Avena coleoptile segments by abscisic acid. Plant Physiol. 51: 93-96 (1979).

(15) Reicosky, D. A. and J. W. Hanover: Seasonal changes in leaf surface waxes of Picea pungons. Amor. J. Bot. 63: 449-456 (1976).

(16) Robards, A. W., H. L. Payne and B. E. S. Gunning: Isolation of the endodermis using walldegrading enzymes. Cytobiologie 13: 85-92 (1976).

(17) Schlienger, C., R.-M. Hofer and P. E. Pilet: Critical study of colcoptile elongation controlled by IAA and ABA. I. Growth kinetics and distribution. Plant \& Cell Physiol. 18: 729-733 (1977).

(18) Schlienger, C., R.-M. Hofer and P. E. Pilet: Hormone-dependent dynamics of wall extension in Tritioum coleoptile segments. In Electron Microscopy 1976 Vol. II Edited by Y. Ben-Shaul. p. $489-491,1976$.

(19) Truelsen, T. A. and A. W. Galston: Changes in growth, auxin- and ribonucleic acid metabolism in wheat colcoptile sections following pulse treatment|with indolyl-3-acetic acid. Physiol. Plant. 19: 167-176 (1966).

(20) Wright, S. T. C.: Multiple and sequential roles of plant growth regulators. In Biochemistry and Physiology of Plant Growth Substances. Edited by F. Wightman and G. Setterfield. p. 521-542. Runge Pres, Ottawa, 1968. 